\section{Бібліометричний аналіз наукових публікацій у журналі «Ендокринологія»}

\section{І.П. Пастер}

ДУ «Інститут ендокринології та обміну речовин ім. В.П. Комісаренка НАМН України»

\begin{abstract}
Резюме. Мета - провести бібліометричний аналіз наукових публікацій у журналі «Ендокринологія». Матеріал і методи. Об'єктом дослідження стали всі номери Журналу за 1996-2020 роки, а предметом дослідження - заголовки рубрик і наукових публікацій, а також (вибірково) наукові публікації або реферати до них. Методи дослідження - відбір, бібліографічна характеристика, групування та системний контент-аналіз наукових публікацій у Журналі. Контент-аналіз, або кількісний аналіз документів полягає в переведенні масової текстової інформації в кількісні показники. Результати. У Журналі опубліковано 935 наукових праць: оригінальних статей, оглядів, лекцій, коротких повідомлень тощо. Останніми роками зростання кількості публікацій пояснюється збільшенням вдвічі кількості номерів на рік (4 замість 2) і зміною формату журналу. Найбільша кількість публікацій припадає на 2012 (54 записи) та 2013 (50 записів) роки. Переважну частину публікацій становлять оригінальні статті (65,4\% від загальної кількості). Співвідношення між публікаціями оригінальних експериментальних і клінічних досліджень становить 1:3. Найбільшу кількість публікацій за клінічною тематикою присвячено цукровому діабету (47,6\% від загальної кількості) та патології щитоподібної залози (25,5\%); понад третина з них - безпосередньо методам лікування. Співвідношення між публікаціями з питань діагностики та лікування перевищує 1:2. У цілому безпосередньо питання діагностики винесено в заголовки 13,0\% публікацій, а питання лікування - 30,3\%. Найбільшу кількість публікацій за експериментальною тематикою присвячено наднирковим (24,1\% від загальної кількості), щитоподібній (23,5\%) і підшлунковій (21,8\%) залозам. У 297 публікаціях (31,8\% від загальної кількості) зазначено по 1 автору, у 186 публікаціях (19,9\%) — по 2, у 161 публікації (17,2\%) — по 3, у 129 публікаціях (13,8\%) — по 4, у 66 публікаціях (7,0\%) - по 5 і в 96 публікаціях (10,3\%) - по 6 і більше. Авторами 483 публікацій зазначено співробітників 153 інших установ або організацій, 16 з яких мали понад 10 публікацій. Співробітники Інституту були авторами 576 публікацій; 37 із них були авторами в 10 і більше публікаціях. Висновки. Останніми роками публікаційна активність залишається стабільною.
\end{abstract}

Ключові слова: журнал «Ендокринологія», наукові публікації, бібліометричний аналіз.

Державну установу «Інститут ендокринології та обміну речовин ім. В.П. Комісаренка НАМН України» (далі - Інститут) було

* Адреса для листування (Correspondence): ДУ «Інститут ендокринології та обміну речовин ім. В.П. Комісаренка НАМН України», вул. Вишгородська, 69, м. Київ, 04114, Україна. E-mail: pasteur@ukr.net

() І.П. Пастер створено згідно з Постановою Кабінету Міністрів України № 1244 від 12.12.1964 року (Наказ Міністерства охорони здоров'я України № 40 від 18.01.1965 року). Наразі Інститут є науковим, консультативним і лікувальним закладом, що надає допомогу дорослим і дітям із 
захворюваннями щитоподібної залози, цукровим діабетом та іншою ендокринною патологією. Інститут є провідною в Україні науководослідною базою для підготовки аспірантів, клінічних ординаторів, захисту докторських i кандидатських дисертацій за фахом «ендокринологія», підготовки фахівців на курсах стажування та інформації, виконує широке коло фундаментальних і прикладних науководослідних робіт.

Також Інститут $є$ засновником науково-практичного медичного журналу «Ендокринологія» (далі - Журнал), який функціонує з квітня 1996 року (свідоцтво про державну реєстрацію КВ № 14099-3070 ПР від 17.06.2008 року) та внесений до Переліку наукових фахових видань України (медичні науки - наказ Міністерства освіти і науки України «Про затвердження рішень Атестаційної колегії Міністерства» від 02.07.2020 року № 886) і (біологічні науки - наказ Міністерства освіти і науки України «Про затвердження рішень Атестаційної колегії Міністерства» від 24.09.2020 року № 1188) [1, 2]. У Журналі публікуються оригінальні статті, огляди, лекції, короткі повідомлення та інші матеріали з фундаментальних і прикладних проблем ендокринології. Кожна стаття або повідомлення супроводжуються анотацією українською, англійською та російською мовами. Повні версії Журналу можна переглянути на офіційному сайті Інституту (www.iem.net.ua/ for-specialists/magazine/) або на офіційній сторінці журналу (www.endokrynologia.com. ua) $[3,4]$.

Журнал індексується в міжнародній наукометричній базі даних «Index Copernicus International», базі даних «Directory of Research Journal Indexing», повнотекстовій базі даних наукових журналів відкритого доступу «Open Academic Journals Index», базі даних «Journals Master List», бібліографічній базі даних «Google Scholar», загальнодержавній реферативній базі даних «Україніка наукова» та базі даних українського реферативного журналу «Джерело». Журнал внесено до реєстру Міжнародного центру періодичних видань (Париж, Франція) під числовим кодом міжнародної ідентифікації ISSN1680-1466.

Тематичні проблеми Журналу: експериментальні та клінічні проблеми ендокринології та метаболізму (діабетологія, тиреоїдологія, патогенез, профілактика, діагностика, терапевтичне та хірургічне лікування, епідеміологія ендокринних захворювань та їх ускладнення, статева патологія, гінекологія тощо). Періодичність виходу номерів Журналу - 4 рази на рік; об'єм - до 12 звичайних друкованих аркушів та 24 опублікованих сторінок; наклад 4000 примірників.

Членами редакційної колегії Журналу є Тронько М.Д., д-р мед. наук, проф., чл.-кор. НАН України, акад. НАМН України (головний редактор), Кваченюк А.М., д-р мед. наук, проф., Соколова Л.К., д-р мед. наук, старш. наук. співроб. (заступники головного редактора з клінічної ендокринології), Ковзун О.I., д-р біол. наук, проф. (заступник головного редактора з експериментальної ендокринологіï), Пастер І.П., канд. мед. наук, старш. наук. співроб. (відповідальний редактор), Богданова T.I., д-р біол. наук, проф., (Київ), Болгов М.Ю., д-р мед. наук, старш. наук. співроб. (Київ), Большова О.В., д-р мед. наук, проф. (Київ), Вендзилович Ю.М. (Львів), Власенко М.В., д-р мед. наук, проф. (Вінниця), Караченцев Ю.І., д-р мед. наук, проф. (Харків), Коваленко А.С., д-р мед. наук, проф. (Київ), Корпачев В.В., д-р мед. наук, проф. (Київ), Кравченко B.I., д-р мед. наук, проф. (Київ), Лучицький С.В., д-р мед. наук, проф. (Київ), Науменко В.Г., канд. мед. наук, доцент (Київ), Орленко В.Л., канд. мед. наук, старш. наук. співроб. (Київ), Полторак В.В., д-р мед. наук, проф. (Харків), Попова В.В., д-р мед. наук, старш. наук. співроб. (Київ), Пушкарьов В.М., д-р біол. наук, старш. наук. співроб. (Київ), Резніков О.Г., д-р мед. наук, проф., чл.-кор. НАН України, акад. НАМН України (Київ), Скрипник Н.В., д-р мед. наук, проф. (ІваноФранківськ), Спринчук Н.А., д-р мед. наук, старш. наук. співроб. (Київ), Товкай О.А., д-р мед. наук, старш. наук. співроб. (Київ), Урбанович А.М., д-р мед. наук, проф. (Львів), Халангот М.Д., д-р мед. наук, доцент (Київ), Мельниченко Г.О., д-р мед. наук, проф., акад. РАН (Російська Федерація), Шестакова М.В., д-р мед. наук, проф., акад. РАН (Російська Федерація), Dagogo-Jack S., проф. медицини, проф. фізіології (Сполучені Штати Америки), i Yamashita S., д-р мед. наук, проф. (Японія). 
Оригінальні дослідження

Мета дослідження - бібліометричний аналіз наукових публікацій у журналі «Ендокринологія» за період з 1996 по 2020 роки.

\section{Методи}

Метод дослідження - відбір, бібліографічна характеристика, групування та системний контент-аналіз наукових публікацій у Журналі. Контент-аналіз, або кількісний аналіз документів полягає в переведенні масової текстової інформації в кількісні показники.

Об'єктом дослідження стали всі номери Журналу за 1996-2020 роки, а предметом дослідження - заголовки рубрик і наукових публікацій, а також (вибірково) наукові публікації або реферати до них.

До аналізу включено основні рубрики Журналу «Оригінальні дослідження», «Короткі повідомлення», «Огляди» і «Лекції», а також допоміжні рубрики «Актуальна інформація», «Випадки 3 практики», «Дискусії, «Діагностика та лікування», «Для практичного лікаря», «3 фахових видань», «Замітки з практики», «Інформаційні матеріали», «Інформація про наукові зібрання», «Історія ендокринології, «Клінічні спостереження», «Клінічні випадки», «Новини світової ендокринології», «Освітній досвід», «Практикуючому лікарю», «Проблеми викладання ендокринології» та
«Суміжні фахівці - ендокринологам». Усі допоміжні рубрики об'єднано в групу «Інші публікації.

3 аналізу виключено інші допоміжні рубрики, зокрема «Новини», «Рецензії, «Хроніка», «Ювілеї» тощо, які не містили достатньої наукової інформації.

Статистичну обробку результатів здійснювали за стандартними методами варіаційної статистики. Показники наведено як середне арифметичне \pm статистична похибка середнього арифметчного ( $\mathrm{M} \pm \mathrm{m})$ і медіана $(\mathrm{Me})$.

\section{Результати та обговорення}

За 25 років видання Журналу в ньому розміщено 935 наукових публікацій. Аналіз розподілу публікацій за роками показав, що в період 1996-2000 роки їх кількість не перевищувала 38 одиниць на рік $(\mathrm{M} \pm \mathrm{m}=33,2 \pm 1,8$; $\mathrm{Me}=34,0 ; \mathrm{n}=5)$, у період 2001-2005 роки цей показник дещо зріс і коливався від 30 до 41 одиниці на рік $(35,4 \pm 2,3 ; 38,0 ; 5)$, у період 2006-2010 роки - від 24 до 38 одиниць на рік (31,8 $\pm 2,3 ; 32,0 ; 5)$, у період 2011-2015 роки від 26 до 54 одиниць на рік $(42,4 \pm 5,2 ; 47,0 ; 5)$ і в період 2016-2020 роки - від 38 до 47 одиниць на рік $(44,2 \pm 1,6 ; 45,0 ; 5)$ (рис.). Останніми роками зростання кількості публікацій пояснюється збільшенням вдвічі кількості

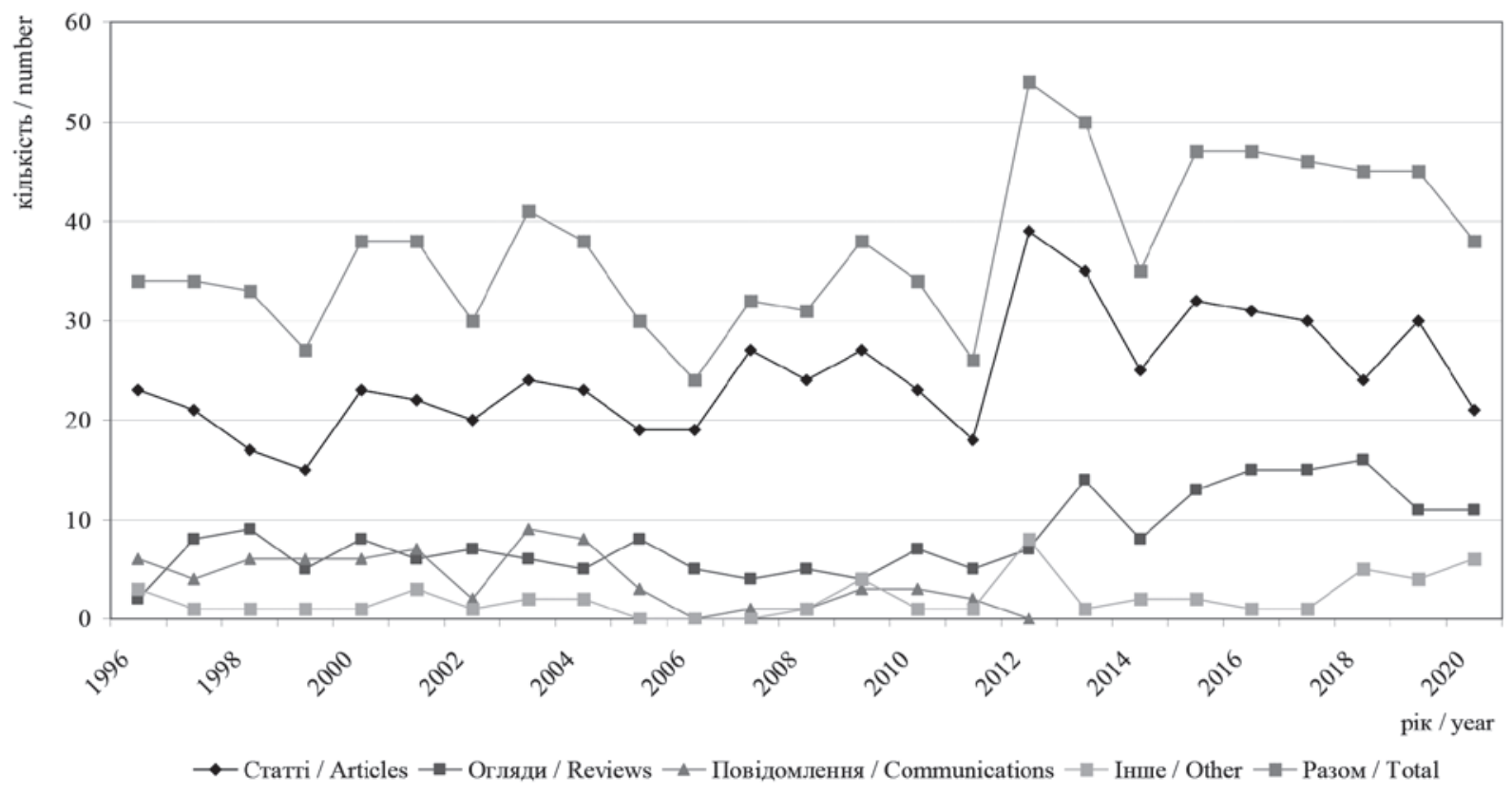

Рис. Розподіл публікацій по роках.

Fig. Distribution of publications by years. 
таблиця 1. Розподіл публікацій за видами

Table 1. Distribution of publications by types

\begin{tabular}{|c|c|c|c|c|c|c|c|}
\hline \multirow[t]{2}{*}{ NN } & \multirow[t]{2}{*}{$\begin{array}{l}\text { Види публікацій } \\
\text { Туре of publications }\end{array}$} & \multicolumn{5}{|c|}{$\begin{array}{l}\text { Періоди публікацій } \\
\text { Publication periods }\end{array}$} & \multirow[t]{2}{*}{$\begin{array}{l}\text { Paзом } \\
\text { Total }\end{array}$} \\
\hline & & $1996-2000$ & 2001-2005 & $2006-2010$ & 2011-2015 & 2016-2020 & \\
\hline 1 & $\begin{array}{l}\text { Оригінальні статті, зокрема: } \\
\text { Original papers, including: }\end{array}$ & $\begin{array}{l}99 \\
59,6 \%\end{array}$ & $\begin{array}{l}108 \\
61,0 \%\end{array}$ & $\begin{array}{l}120 \\
75,5 \%\end{array}$ & $\begin{array}{l}149 \\
70,3 \%\end{array}$ & $\begin{array}{l}136 \\
61,5 \%\end{array}$ & $\begin{array}{l}612 \\
65,4 \%\end{array}$ \\
\hline 1.1 & $\begin{array}{l}\text { експериментальні } \\
\text { experimental }\end{array}$ & 37 & 29 & 38 & 24 & 22 & 150 \\
\hline 1.2 & $\begin{array}{l}\text { клінічні } \\
\text { clinical }\end{array}$ & 62 & 79 & 82 & 125 & 114 & 462 \\
\hline 2 & $\begin{array}{l}\text { Огляди і лекції } \\
\text { Reviews and lectures }\end{array}$ & $\begin{array}{l}32 \\
19,3 \%\end{array}$ & $\begin{array}{l}32 \\
18,1 \%\end{array}$ & $\begin{array}{l}25 \\
15,7 \%\end{array}$ & $\begin{array}{l}47 \\
22,2 \%\end{array}$ & $\begin{array}{l}68 \\
30,8 \%\end{array}$ & $\begin{array}{l}204 \\
21,8 \%\end{array}$ \\
\hline 3 & $\begin{array}{l}\text { Короткі повідомлення, зокрема } \\
\text { Short communications, including: }\end{array}$ & $\begin{array}{l}28 \\
16,9 \%\end{array}$ & $\begin{array}{l}29 \\
16,4 \%\end{array}$ & $\begin{array}{l}8 \\
5,0 \%\end{array}$ & $\begin{array}{l}2 \\
0,9 \%\end{array}$ & $\begin{array}{l}0 \\
0,0 \%\end{array}$ & $\begin{array}{l}67 \\
7,2 \%\end{array}$ \\
\hline 3.1 & $\begin{array}{l}\text { експериментальні } \\
\text { experimental }\end{array}$ & 9 & 6 & 5 & 1 & 0 & 21 \\
\hline 3.2 & $\begin{array}{l}\text { клінічні } \\
\text { clinical }\end{array}$ & 19 & 23 & 3 & 1 & 0 & 46 \\
\hline 4 & $\begin{array}{l}\text { Iнше } \\
\text { Other }\end{array}$ & $\begin{array}{l}7 \\
4,2 \%\end{array}$ & $\begin{array}{l}8 \\
4,5 \%\end{array}$ & $\begin{array}{l}6 \\
3,8 \%\end{array}$ & $\begin{array}{l}14 \\
6,6 \%\end{array}$ & $\begin{array}{l}17 \\
7,7 \%\end{array}$ & $\begin{array}{l}52 \\
5,6 \%\end{array}$ \\
\hline 5 & $\begin{array}{l}\text { Разом } \\
\text { Total }\end{array}$ & $\begin{array}{l}166 \\
100,0 \%\end{array}$ & $\begin{array}{l}177 \\
100,0 \%\end{array}$ & $\begin{array}{l}159 \\
100,0 \%\end{array}$ & $\begin{array}{l}212 \\
100,0 \%\end{array}$ & $\begin{array}{l}221 \\
100,0 \%\end{array}$ & $\begin{array}{l}935 \\
100,0 \%\end{array}$ \\
\hline
\end{tabular}

Примітка: відсотки вказано від загальної кількості публікачій за кожний період і за весь час.

Note: the percentage is indicated from the total number of publications for each period and for all time.

номерів на рік (4 замість 2) і зміною формату журналу.

За аналізований період публікації в Журналі було представлено оригінальними статтями, оглядами та лекціями, короткими повідомленнями, а також іншими науковими працями. Співвідношення різних видів публікацій змінювалося з часом (табл. 1). Так, частка оригінальних статей спочатку зросла від 59,6\% у період з 1996 по 2000 рік до 75,5\% у період з 2006 по 2010 рік, після чого майже повернулася до початкового рівня (61,5\% у період з 2016 по 2020 рік). Серед оригінальних статей постійно зростає частка публікацій із клінічної тематики: якщо в період з 1996 по 2000 рік вона становила $62,6 \%$, то в період з 2016 до 2020 року збільшилася до 83,8\%. За період аналізу відповідні показники зросли для оглядів/ лекцій (з 19,3\% до 30,8\%) і для інших наукових праць ( 3 4,2\% до 7,7\%). Щодо коротких повідомлень, то їх частка постійно знижувалася, а з 2012 року публікацію було призупинено.

За результатами кількісного аналізу з'ясовано, що майже половина всіх публікацій у Журналі за клінічними напрямами (351 одиниця, 47,6\% від загальної кількості) стосується проблем цукрового діабету (насамперед 2-го типу) і понад третина з них (124 одиниці, 35,3\%) - безпосередньо методів лікування (табл. 2). На другому місці за кількістю (188 одиниць, 25,5\% від загальної кількості) публікації з проблем захворювань щитоподібної залози з майже рівномірним розподілом на злоякісну та доброякісну патологію. Що стосується патології росту, обміну речовин, надниркових і статевих залоз, то загальна кількість публікацій становила 71 одиницю (9,7\% від загальної кількості), а основна увага приділялася питанням лікування. У цілому безпосередньо питання діагностики винесено в заголовки 13,0\% публікацій, а питання лікування - 30,3\%.

Серед публікацій за експериментальними напрямками однакові частки (майже по чверті від загальної кількості) становлять публікації за результатами досліджень, які стосуються щитоподібної, підшлункової та надниркових залоз (табл. 3).

У 297 публікаціях (31,8\% від загальної кількості) зазначено по 1 автору, у 186 публікаціях (19,9\%) - по 2, у 161 публікації $(17,2 \%)-$ по 3, у 129 публікаціях (13,8\%) - по 4, у 66 публікаціях $(7,0 \%)$ - по 5 і в 96 публікаціях $(10,3 \%)-$ по 6 і більше. Тобто, понад половину 
Таблиця 2. Розподіл публікацій за клінічними напрямами Table 2. Distribution of publications by clinical directions

\begin{tabular}{|c|c|c|c|c|}
\hline \multirow[t]{2}{*}{ NN } & \multirow{2}{*}{$\begin{array}{l}\text { Об'єкти } \\
\text { публікацій } \\
\text { Objects of } \\
\text { publications }\end{array}$} & \multirow{2}{*}{$\begin{array}{l}\text { Кількість } \\
\text { публікацій } \\
\text { Number of } \\
\text { publications }\end{array}$} & \multicolumn{2}{|l|}{$\begin{array}{l}\text { Зокрема } \\
\text { Including }\end{array}$} \\
\hline & & & $\begin{array}{l}\text { діагнос- } \\
\text { тика } \\
\text { diagnosis }\end{array}$ & $\begin{array}{l}\text { лікуван- } \\
\text { ня } \\
\text { treatment }\end{array}$ \\
\hline 1 & $\begin{array}{l}\text { Цукровий діабет, } \\
\text { зокрема: } \\
\text { Diabetes mellitus, } \\
\text { including: }\end{array}$ & $\begin{array}{l}351 \\
47,6 \%\end{array}$ & $\begin{array}{l}31 \\
8,8 \%\end{array}$ & $\begin{array}{l}124 \\
35,3 \%\end{array}$ \\
\hline 1.1 & $\begin{array}{l}\text { 1-го типу } \\
\text { type } 1\end{array}$ & 89 & $\begin{array}{l}8 \\
9,0 \%\end{array}$ & $\begin{array}{l}36 \\
40,4 \%\end{array}$ \\
\hline 1.2 & $\begin{array}{l}\text { 2-го типу } \\
\text { type } 2\end{array}$ & 143 & $\begin{array}{l}8 \\
5,6 \%\end{array}$ & $\begin{array}{l}43 \\
30,1 \%\end{array}$ \\
\hline 2 & $\begin{array}{l}\text { Патологія } \\
\text { щитоподібної } \\
\text { залози, зокрема: } \\
\text { Thyroid pathology, } \\
\text { including }\end{array}$ & $\begin{array}{l}188 \\
25,5 \%\end{array}$ & $\begin{array}{l}37 \\
19,7 \%\end{array}$ & $\begin{array}{l}65 \\
34,6 \%\end{array}$ \\
\hline 2.1 & $\begin{array}{l}\text { злоякісна } \\
\text { malignant }\end{array}$ & 73 & $\begin{array}{l}14 \\
19,2 \%\end{array}$ & $\begin{array}{l}26 \\
35,6 \%\end{array}$ \\
\hline 2.2 & $\begin{array}{l}\text { доброякісна } \\
\text { benign }\end{array}$ & 80 & $\begin{array}{l}15 \\
18,8 \%\end{array}$ & $\begin{array}{l}28 \\
35,0 \%\end{array}$ \\
\hline 3 & $\begin{array}{l}\text { Патологія } \\
\text { надниркових } \\
\text { залоз } \\
\text { Adrenal pathology }\end{array}$ & $\begin{array}{l}27 \\
3,7 \%\end{array}$ & $\begin{array}{l}6 \\
22,2 \%\end{array}$ & $\begin{array}{l}9 \\
33,3 \%\end{array}$ \\
\hline 4 & $\begin{array}{l}\text { Патологія } \\
\text { статевих залоз } \\
\text { Gonadal pathology }\end{array}$ & $\begin{array}{l}22 \\
3,0 \%\end{array}$ & 1 & $\begin{array}{l}7 \\
31,8 \%\end{array}$ \\
\hline 5 & $\begin{array}{l}\text { Патологія росту } \\
\text { Disorders of } \\
\text { growth }\end{array}$ & $\begin{array}{l}12 \\
1,6 \%\end{array}$ & $\begin{array}{l}3 \\
25,0 \%\end{array}$ & $\begin{array}{l}4 \\
33,3 \%\end{array}$ \\
\hline 6 & $\begin{array}{l}\text { Патологія обміну } \\
\text { речовин } \\
\text { Pathology of } \\
\text { metabolism }\end{array}$ & $\begin{array}{l}10 \\
1,4 \%\end{array}$ & $\begin{array}{l}1 \\
10,0 \%\end{array}$ & $\begin{array}{l}4 \\
40,0 \%\end{array}$ \\
\hline 7 & $\begin{array}{l}\text { Інша патологія } \\
\text { Other pathology }\end{array}$ & $\begin{array}{l}48 \\
6,5 \%\end{array}$ & $\begin{array}{l}16 \\
33,3 \%\end{array}$ & $\begin{array}{l}10 \\
20,8 \%\end{array}$ \\
\hline 8 & $\begin{array}{l}\text { Iнше } \\
\text { Other }\end{array}$ & $\begin{array}{l}79 \\
10,7 \%\end{array}$ & $\begin{array}{l}1 \\
1,3 \%\end{array}$ & - \\
\hline 9 & $\begin{array}{l}\text { Разом } \\
\text { Total }\end{array}$ & $\begin{array}{l}737 \\
100,0 \%\end{array}$ & $\begin{array}{l}96 \\
13,0 \%\end{array}$ & $\begin{array}{l}223 \\
30,3 \%\end{array}$ \\
\hline
\end{tabular}

Примітка: у колонці «Кількість публікацій» відсотки вказано від загальної кількості публікачій, у колонках «діагностика» та «лікування» — від кількості публікачій із певної патології. Note: in the column «Number of publications» the percentage is indicated from the total number of publications, in the columns «diagnosis» and «treatment» - from the number of publications from a particular pathology.

публікацій (51,7\% від загальної кількості) написано одним або двома співавторами.

Крім співробітників Інституту, авторами або співавторами 483 публікацій
Таблиця 3. Розподіл публікацій за експериментальними напрямами

Table 3. Distribution of publications by experimental directions

\begin{tabular}{|c|c|c|c|c|}
\hline NN & $\begin{array}{l}\text { Об'єкти публікацій } \\
\text { Objects of } \\
\text { publications }\end{array}$ & $\begin{array}{l}\text { Оригі- } \\
\text { нальні } \\
\text { статті } \\
\text { Original } \\
\text { articles }\end{array}$ & $\begin{array}{l}\text { Короткі } \\
\text { повідо- } \\
\text { млення } \\
\text { Short } \\
\text { commu- } \\
\text { nications }\end{array}$ & $\begin{array}{l}\text { Загальна } \\
\text { кількість } \\
\text { Total } \\
\text { number }\end{array}$ \\
\hline 1 & $\begin{array}{l}\text { Щитоподібна залоза } \\
\text { The thyroid gland }\end{array}$ & $\begin{array}{l}34 \\
23,0 \%\end{array}$ & $\begin{array}{l}6 \\
27,4 \%\end{array}$ & $\begin{array}{l}40 \\
23,5 \%\end{array}$ \\
\hline 2 & $\begin{array}{l}\text { Прищитоподібна залоза } \\
\text { The parathyroid gland }\end{array}$ & $\begin{array}{l}4 \\
2,7 \%\end{array}$ & $\begin{array}{l}0 \\
0,0 \%\end{array}$ & $\begin{array}{l}4 \\
2,4 \%\end{array}$ \\
\hline 3 & $\begin{array}{l}\text { Підшлункова залоза } \\
\text { The pancreas }\end{array}$ & $\begin{array}{l}34 \\
23,0 \%\end{array}$ & $\begin{array}{l}3 \\
13,6 \%\end{array}$ & $\begin{array}{l}37 \\
21,8 \%\end{array}$ \\
\hline 4 & $\begin{array}{l}\text { Надниркові залози } \\
\text { The adrenals gland }\end{array}$ & $\begin{array}{l}34 \\
23,0 \%\end{array}$ & $\begin{array}{l}7 \\
31,8 \%\end{array}$ & $\begin{array}{l}41 \\
24,1 \%\end{array}$ \\
\hline 5 & $\begin{array}{l}\text { Статеві залози } \\
\text { The gonads }\end{array}$ & $\begin{array}{l}16 \\
10,8 \%\end{array}$ & $\begin{array}{l}3 \\
13,6 \%\end{array}$ & $\begin{array}{l}19 \\
11,2 \%\end{array}$ \\
\hline 6 & $\begin{array}{l}\text { Iнше } \\
\text { Other }\end{array}$ & $\begin{array}{l}26 \\
17,5 \%\end{array}$ & $\begin{array}{l}3 \\
13,6 \%\end{array}$ & $\begin{array}{l}29 \\
17,0 \%\end{array}$ \\
\hline 7 & $\begin{array}{l}\text { Разом } \\
\text { Total }\end{array}$ & $\begin{array}{l}148 \\
100,0 \%\end{array}$ & $\begin{array}{l}22 \\
100,0 \%\end{array}$ & $\begin{array}{l}170 \\
100,0 \%\end{array}$ \\
\hline
\end{tabular}

Примітка: відсотки вказано від загальної кількості кожного виду публікачій.

Note: the percentage is indicated from the total number of each type of publication.

зазначеноспівробітників 153 інших установ або організацій, 16 з яких мали понад 10 публікацій у Журналі (табл. 4). Менше публікацій подано співробітниками Вінницького національного медичного університету ім. М.І. Пирогова МОЗ України (9 публікацій), Тернопільського державного медичного університету ім. І.Я. Горбачевського МОЗ України, ДУ «Дніпропетровська медична академія МОЗ України» (8 публікацій), Вінницького обласного клінічного високоспеціалізованого ендокринологічного центру МОЗ України, ДУ «Національний інститут раку НАМН України» (по 7 публікацій), Київський національний університет ім. Тараса Шевченка і ДУ «Національний науковий центр «Інститут кардіології ім. акад. М.Д. Стражеска» НАМН України» (по 5 публікацій). Ще 9 установ або організацій мають по 4 публікації, 11 - по 3, 26 - по 2 і 84 - по 1. (Сума публікацій всіх установ перевищує загальну кількість публікацій в Журналі за рахунок співавторства).

Слід відзначити, що авторами цих публікацій були також співробітники 25 зарубіжних установ, зокрема National Cancer Institure (Rockville, MD, USA), National 
Таблиця 4. Активність Інституту та інших установ за публікаціями в Журналі

Table 4. Activity of Institute and other institution by publications in Journal

\section{NN Установи Institutions}

\section{Загальна \\ кількість Total number}

зокрема самостійних including independent
1 ДУ «Інститут проблем ендокринної патології ім. В.Я. Данилевського НАМН України» 58

41

$\mathrm{SI}$ «V. Danilevsky Institute for Endocrine Pathology Problems of the National Academy of Medical Science of Ukraine»

2 Національний медичний університет ім. О.О. Богомольця МОЗ України O.O. Bogomolets National Medical University of the Ministy of Health of Ukraine

3 Національна медична академія післядипломної освіти ім. П.Л. Шупика МОЗ України P.L. Shupyk National Medical Academy of Postgraduate Education of the Ministy of Health of Ukraine

4 Харківська медична академія післядипломної освіти МОЗ України Kharkiv Medical Academy of Postgraduate Education of the Ministy of Health of Ukraine

5 ДУ «Інститут геронтології ім. Д.Ф. Чеботарьова НАМН України»

SI «D.F. Chebotarev Institute of Gerontology of the National Academy of Medical Science of Ukraine»

6 Український науково-практичний центр ендокринної хірургії, трансплантації ендокринних органів і тканин МОЗ України Ukrainian Scientific and Practical Center of Endocrine Surgery, Transplantation of Endocrine Organs and Tissues of the Ministy of Health of Ukraine

7 Донецький національний медичний університет МОЗ України Donetsk National Medical University of the Ministy of Health of Ukraine

8 Харківський національний медичний університет МОЗ України Kharkiv National Medical University of the Ministy of Health of Ukraine

9 ДУ «Національний науковий центр радіаційної медицини НАМН України» SI «National Research Center for Radiation Medicine of the National Academy of Medical Science of Ukraine»

10 Івано-Франківський національний медичний університет МО3 України Ivano-Frankivsk National Medical University of the Ministy of Health of Ukraine

11 ДУ «Інститут охорони здоров'я дітей та підлітків НАМН України»

SI «Institute for Children and Adolescents Health Care of the National Academy of Medical Science of Ukraine»

12 Інститут біохімії ім. О.В. Палладіна НАН України O.V. Palladin Institute of Biochemistry of the National Academy of Science of Ukraine

13 Львівський національний медичний університет ім. Данила Галицького МОЗ України Danylo Halytsky Lviv National Medical University of the Ministy of Health of Ukraine

14 Буковинський державний медичний університет МО3 України Bukovinian State Medical University of the Ministy of Health of Ukraine

15 Інституту фізіології ім. О.О. Богомольця НАН України O.O. Bogomoletz Institute of Physiology of the National Academy of Science of Ukraine

16 ДУ «Інститут педіатрії, акушерства і гінекології НАМН України» 56

SI «Institute of Pediatrics, Obstetrics and Gynecology of the National Academy of Medical Science of Ukraine»

Bсього

Total

ДУ «Інститут ендокринології та обміну речовин ім. В.П. Комісаренка НАМН України»

SI «V. Komisarenko Institute of Endocrinology and Metabolism of the National Academy of Medical Science of Ukraine» 
Institute for Public Health and the Environmemt (Bilthoven, Netherlands) (по 3 публікацii); Columbia University (New York, NY, USA), Federal University of São Paulo (São Paulo, Brazil), Philipps University (Marburg, Germany), University of North Carolina at Charlotte (North Carolina, Charlotte, USA), Региональный диагностический центр (Алматы, Республика Казахстан) (по 2 публікаціi); Bath University (Bath, UK), European Centre for Ecology and Health Protection, World Health Organization (Rome, Italy), European Centre for Environmental Health, World Health Organization (Copenhagen, Denmark), Hoechst A.G. (Frankfurt-onMain, Germany), Institute of Parasitology and Biomedicine (Granada, Spain), Johannes Gutenberg University (Mainz, Germany), Karolinska University Hospital (Huddinge, Stockholm, Sweden), Oakland University (Rochester, MI, USA), Romanian Telemedicine Center (Bucharest, Romania), State University of Medicine and Pharmacy «Nicolae Testemitanu» (Chisinau, Republic Moldova), Tehran University of Medical Sciences (Tehran, Iran), University of Georgia (Athens, Georgia, USA), University School of Medical Sciences (Poznan, Poland), Інститут вуха, горла, носа, Центр щитовидної залози, «Проект Чорнобиль» (Нью-Йорк, США), Институт диабета университета Улм (Улм, Німеччина), Государственный университет медицины и фармации им. Н. Тестемицану (Кишинев, Молдова), НИИ клинической медицины им. М.А. Топчибашева (Баку, Азербайджан), Республиканский специализированный научно-практический медицинский центр эндокринологии М3 Республики Узбекистан (Ташкент, Республіка Узбекистан) (по 1 публікації).

Співробітники Інституту були авторами 576 публікацій, з яких 452 (78,5\% від загальної кількості) написані самостійно, а 124 (21,5\%) - у співавторстві зі співробітниками інших наукових установ або організацій. 37 співробітників Інституту були авторами або співавторами в 10 і більше публікаціях (табл. 5). 26 осіб і надалі продовжують працювати в Інституті.

Крім вказаних наукових публікацій, у періодичних номерах Журналу було розміщено:
1) матеріали науково-практичної конференції, присвяченої 80-річчю Українського НДІ фармакотерапії ендокринних захворювань (м. Харків, 17-19 листопада 1999 року) 1999;4(2):189-304;

2) матеріали I науково-практичної конференції молодих вчених, присвяченої 95-річчю від дня народження акад. В.П. Комісаренка (м. Київ, 30-31 січня 2002 року) - 2002;7(1):101-49;

$3)$ рішення Пленуму Асоціації ендокринологів України (м. Київ, 27 травня 2005 року) 2005;10(2):256-8;

4) матеріали науково-практичної конференції 20 років після Чорнобильської катастрофи» (м. Київ, 16 березня 2006 року) 2006;11(1):80-141;

$5)$ тези науково-практичної конференції «Актуальні питання діагностики та лікування дитячої ендокринної патології» (м. Київ, 8-9 червня 2006 року) - 2006;11(2):249-70;

6) тези науково-практичної конференції «Актуальні Проблеми тиреоїдології» (м. Київ, 1415 жовтня 2010 року) - 2010;15(2):313-55;

7) тези конференції молодих вчених $\mathrm{IH}^{-}$ ституту ендокринології та обміну речовин ім. В.П. Комісаренка НАМН України (м. Київ, 17 лютого 2011 року) 2011;16(1):114-124;

8) матеріали науково-практичної конференції «Новітні технології в діагностиці, профілактиці та лікуванні найбільш поширених ендокринних захворювань» (м. Львів, 2526 жовтня 2012 року) - 2012;17(4):5-9;

9) тези конференції молодих учених ДУ «Інститут ендокринології та обміну речовин ім. В.П. Комісаренка НАМН України» (м. Львів, 25 квітня 2013 року) 2013;18(3):84-9.

В окремих номерах Журналу розміщено:

1) матеріали VI з’ізду ендокринологів України (до 10-річчя незалежності України) (м. Київ, 23-25 травня 2001 року) - 2001, Т. 6, додаток;

2) матеріали VII з'їзду ендокринологів України (до 100-річчя від дня народження В.П. Комісаренка) (м. Київ, 15-18 травня 2007 року) - 2007, Т. 12, додаток;

3) матеріали I конгресу Асоціації ендокринологів України (м. Київ, 21-23 квітня 2010 року) - 2010, Т. 15, додаток; 
Таблиця 5. Активність науковців Інституту за публікаціями у Журналі

Table 5. Activity of the scientists of Institute by publications in Journal

\begin{tabular}{|c|c|c|c|c|c|c|c|}
\hline NN & $\begin{array}{l}\text { Науковці } \\
\text { Scientists }\end{array}$ & $\begin{array}{l}\text { Оригінальні } \\
\text { статті } \\
\text { Original } \\
\text { papers }\end{array}$ & $\begin{array}{l}\text { Огляди та } \\
\text { лекції } \\
\text { Reviews and } \\
\text { lectures }\end{array}$ & $\begin{array}{l}\text { Короткі по- } \\
\text { відомлення } \\
\text { Short com- } \\
\text { munications }\end{array}$ & $\begin{array}{l}\text { Інші публі- } \\
\text { кації } \\
\text { Other } \\
\text { publications }\end{array}$ & $\begin{array}{l}\text { Загальна } \\
\text { кількість } \\
\text { Total } \\
\text { number }\end{array}$ & $\begin{array}{l}\text { зокрема, } \\
\text { самостійних } \\
\text { including } \\
\text { independent }\end{array}$ \\
\hline 1 & Тронько М.Д. / Tronko M.D. & 60 & 41 & 7 & 11 & 119 & 5 \\
\hline 2 & Ковзун O.І. / Kovzun O.I. & 37 & 10 & 4 & 2 & 53 & 1 \\
\hline 3 & Пушкарьов B.M. / Pushkarev V.M. & 22 & 14 & 4 & 3 & 43 & 5 \\
\hline 4 & Пастер І.П. / Pasteur I.P. & 10 & 20 & 4 & 7 & 41 & 9 \\
\hline 5 & Соколова Л.K. / Sokolova L.K. & 18 & 15 & 1 & 1 & 35 & 4 \\
\hline 6 & Коваленко A.Є. / Kovalenko A. Ye. & 20 & 12 & 2 & 1 & 35 & 0 \\
\hline 7 & Рибаков С.Й. / Rybakov S.I. & 10 & 20 & 3 & 1 & 34 & 18 \\
\hline 8 & Кравченко B.I. / Kravchenko V.I. & 26 & 2 & 0 & 0 & 28 & 0 \\
\hline 9 & Єфімов A.C. / Efimov A.S. & 16 & 6 & 3 & 1 & 26 & 1 \\
\hline 10 & Большова O.B. / Bolshova O.V. & 11 & 8 & 3 & 2 & 24 & 0 \\
\hline 11 & Богданова T.I. / Bogdanova T.I. & 21 & 1 & 0 & 0 & 22 & 1 \\
\hline 12 & Кваченюк А.M. / Kvachenyuk A.M. & 13 & 7 & 0 & 1 & 21 & 3 \\
\hline 13 & $\begin{array}{l}\text { Маньковський Б.М. / } \\
\text { Mankovsky B.M. }\end{array}$ & 15 & 4 & 0 & 2 & 21 & 2 \\
\hline 14 & Корпачов В.B. / Korpachev V.V. & 14 & 5 & 1 & 1 & 21 & 1 \\
\hline 15 & Ткач C.M. / Tkach S.M. & 18 & 1 & 0 & 1 & 20 & 9 \\
\hline 16 & Левчук H.I. / Levchuk N.I. & 17 & 1 & 1 & 1 & 20 & 2 \\
\hline 17 & Болгов М.Ю. / Bolgov M. Yu. & 14 & 5 & 0 & 1 & 20 & 1 \\
\hline 18 & Зубкова С.T. / Zubkova S.T. & 19 & 0 & 1 & 0 & 20 & 0 \\
\hline 19 & Замотаєва Г.A. / Zamotayeva G.A. & 16 & 3 & 0 & 0 & 19 & 0 \\
\hline 20 & Мікоша O.C. / Mikosha O.S. & 15 & 1 & 3 & 0 & 19 & 0 \\
\hline 21 & Воскобойник Л.Г. / Voskoboynyk L.H. & 16 & 1 & 0 & 0 & 17 & 8 \\
\hline 22 & $\begin{array}{l}\text { Корпачова-Зінич O.B./ Korpacheva- } \\
\text { Zinych O.V. }\end{array}$ & 14 & 2 & 0 & 1 & 17 & 1 \\
\hline 23 & Мішуніна T.M. / Myshunina T.M. & 16 & 0 & 0 & 0 & 16 & 2 \\
\hline 24 & Олійник B.A. / Olyinyk V.A. & 11 & 3 & 0 & 2 & 16 & 2 \\
\hline 25 & Гуда Б.Б. / Guda B.B. & 10 & 4 & 0 & 1 & 15 & 1 \\
\hline 26 & Зурнаджи Л.Ю. / Zurnadzhy L. Yu. & 14 & 1 & 0 & 0 & 15 & 0 \\
\hline 27 & Комісаренко І.B. / Komisarenko I.V. & 12 & 0 & 1 & 1 & 14 & 0 \\
\hline 28 & Резніков О.Г. / Reznikov O.G. & 12 & 0 & 0 & 1 & 13 & 3 \\
\hline 29 & Лучицький Є.B. / Luchytsky Ye.V. & 7 & 5 & 1 & 0 & 13 & 0 \\
\hline 30 & Tерехова Г.M. / Terekhova G.M. & 13 & 0 & 0 & 0 & 13 & 0 \\
\hline 31 & Ковальчук A.B. / Kovalchuk A.V. & 9 & 1 & 0 & 2 & 12 & 1 \\
\hline 32 & Гулеватий C.B. / Gulevaty S.V. & 10 & 2 & 0 & 0 & 12 & 0 \\
\hline 33 & Калініченко O.B. / Kalinichenko O.V. & 12 & 0 & 0 & 0 & 12 & 0 \\
\hline 34 & Зелінська Г.B. / Zelinska G.V. & 10 & 1 & 0 & 0 & 11 & 5 \\
\hline 35 & Лучицький B.Є. / Luchytsky V. Ye. & 8 & 3 & 0 & 0 & 11 & 3 \\
\hline 36 & Калинська Л.M. / Kalynska L.M. & 9 & 1 & 0 & 0 & 10 & 2 \\
\hline 37 & Безверха Т.П. / Bezverha Т.P. & 7 & 3 & 0 & 0 & 10 & 0 \\
\hline
\end{tabular}


4) матеріали II конгресу Асоціації ендокринологів України (м. Київ, 1819 квітня 2012 року) - 2012, Т. 17, № 1, додаток 1 ;

5) тези VIII з’їзду Асоціації ендокринологів України (м. Київ, 20-22 жовтня 2014 року) 2014, Т. 19, № 4;

6) тези до науково-практичної конференції «Пріоритетні проблеми ендокринної хірургіï» - 2018, Т. 23, № 1, додаток 1;

7 «Современные взгляды на патогенетические аспекты и стратегии лечения больных сахарным диабетом с COVID-19» - 2020, Т. 25, спецвипуск 2.

Як додаток до першого номера Журналу за 2012-2016 роки видавався «Довідник основних показників діяльності ендокринологічної служби України».

Отже, протягом 25 років у Журналі опубліковано 935 наукових праць, що свідчить про високу публікаційну активність видання.

\section{Висновки}

1. У Журналі опубліковано 935 наукових праць протягом 1996-2020 років.

2. Переважну частину публікацій становлять оригінальні статті (65,4\% від загальної кількості).

3. Співвідношення між публікаціями оригінальних експериментальних і клінічних досліджень становить 1:3.

4. Найбільшу кількість публікацій за клінічною тематикою присвячено цукровому діабету (47,6\% від загальної кількості) та патології щитоподібної залози (25,5\%).

5. Співвідношення між публікаціями з питань діагностики та лікування перевищує 1:2.

6. Найбільшу кількість публікацій за експериментальною тематикою присвячено наднирковим (24,1\% від загальної кількості), щитоподібній (23,5\%) і підшлунковій (21,8\%) залозам.

7. Останніми роками публікаційна активність залишається стабільною.

\section{Список використаної літератури}

1. Міністерство освіти і науки України. Наказ «Про затвердження рішень Атестаційної колегії Міністерства» від 02.07.2020 року № 886 (Ministry of Health of Ukraine. Order from 02.07.2020 N886 «On approval of decisions of the Certification
Board of the Ministry»). [Internet] Available from: https://mon. gov.ua/ua/npa/pro-zatverdzhennya-rishen-atestacijnoyi-kolegiyiministerstva-vid-2-lipnya-2020-roku.

2. Міністерство освіти і науки України. Наказ «Про затвердження рішень Атестаційної колегії Міністерства» від 24.09.2020 року № 1188 (Ministry of Health of Ukraine. Order from 24.09.2020 N1188 «On approval of decisions of the Certification Board of the Ministry»). [Internet] Available from: https://mon. gov.ua/ua/npa/pro-zatverdzhennya-rishen-atestacijnoyi-kolegiyiministerstva-vid-24-veresnya-2020-roku.

3. www.iem.net.ua/for-specialists/magazine/.

4. www.endokrynologia.com.ua.

(Надійшла до редакиії 24.11.2020 p.)

\section{Библиометрический анализ научных публикаций в журнале «Ендокринологія»}

\section{И.П. Пастер}

ГУ «Институт эндокринологии и обмена веществ им. В.П. Комиссаренко НАМН Украины»

Резюме. Цель - провести библиометрический анализ научных публикаций в журнале «Ендокринологія». Материал и методы. Объектом исследования стали все номера журнала за 1996-2020 годы, а предметом исследования - заголовки рубрик и научных публикаций, а также (выборочно) научные публикации или рефераты к ним. Методы исследования — отбор, библиографическая характеристика, группировка и системный контент-анализ научных публикаций в журнале. Контент-анализ, или количественный анализ документов заключается в переводе массовой текстовой информации в количественные показатели. Результаты. В журнале опубликовано 935 научных работ: оригинальных статей, обзоров, лекций, кратких сообщений и другие. В последние годы возростание количества публикаций объясняется увеличением вдвое количества номеров за год (4 вместо 2) и изменением формата журнала. Наибольшее количество публикаций приходится на 2012 (54 записи) и 2013 (50 записей) годы. Большую часть публикаций составляют оригинальные исследования (65,4\% от общего количества). Соотношение между публикациями оригинальных экспериментальных и клинических исследований составляет 1:3. Наибольшее количество публикаций по клинической тематике посвящено сахарному диабету $(47,6 \%$ от общего количества) и патологии щитовидной железы (25,5\%); более трети из них - непосредственно методам лечения. Соотношение между публикациями по вопросам диагностики и лечения превышает 1:2. В целом, непосредственно вопросы диагностики вынесены в заглавия 13,0\% публикаций, а вопросы лечения - 30,3\%. Наибольшее количество публикаций по экспериментальной тематике посвящено надпочечным (24,1\% от общего количества), щитовидной $(23,5 \%)$ и поджелудочной $(21,8 \%)$ железам. В 297 публикациях (31,8\% от общего количества) указано по 1 автору, в 186 публикациях (19,9\%) - по 2, в 161 публикации (17,2\%) — по 3, в 129 публикациях (13,8\%) - по 4, в 66 публикациях (7,0\%) - по 5 и в 96 публикациях (10,3\%) - по 6 и больше. Авторами 483 публикаций указано сотрудников 153 других учреждений или организаций, 
16 из которых имели более 10 публикаций. Сотрудники Института были авторами 576 публикаций; 37 из них были авторами 10 и более публикаций. Выводы. В последние годы публикационная активность остается стабильной.

Ключевые слова: журнал «Ендокринологія», научные публикации, библиометрический анализ.

\section{Bibliometric analysis of scientific publication in journal «Endokrynologia»}

\section{I.P. Pasteur}

SI «V.P. Komisarenko Institute of Endocrinology and Metabolism of the National Academy of Medical Sciences of Ukraine»

Abstract. The aim is to conduct a bibliometric analysis of scientific publications in the journal «Endokrynologia». Material and methods. The object of the study were all the issues of the Journal for 1996-2020, and the subject of research were headings and scientific publications, as well as (selectively) scientific publications or abstracts to them. Methods of research - selection, bibliographic description, grouping and systematic content analysis of scientific publications in the Journal. Content analysis, or a quantitative analysis of documents, consists in translating the mass textual information into quantitative indicators. Results. The Journal published 935 scientific works: original articles, reviews and lectures, short messages, etc. In recent years, the increase in the number of publications is due to doubling the number of issues per year (4 instead of 2 ) and changing the format of Journal. The largest number of articles was published in 2012 (54 titles) and 2013 (50 titles) years. Most of the publications are original articles ( $65.4 \%$ of the total). The ratio between publications of original experimental and clinical studies is $1: 3$. The largest number of publications on clinical topics is devoted to diabetes mellitus (47.6\% of the total) and thyroid pathology
(25.5\%); more than a third of them - directly to treatment methods. The ratio between publications on diagnosis and treatment exceeds 1:2. In general, the problem of diagnosis was directly noted in the titles of $13.0 \%$ publications, and the problem of treatment in the titles of $30.3 \%$ publications. Also a large number of publications on experimental topics is devoted to the adrenal (24.1\% of the total), thyroid (23.5\%) and pancreas (21.8\%) glands. One author is mentioned in 297 publications (31.8\% of the total number), two in 186 publications (19.9\%), three - in 161 publications (17.2\%), four — in 129 publications 13.8\%) - 4, five — in 66 publications (7.0\%) and six or more - in 96 publications (10.3\%). The authors of 483 publications of Journal were researchers from 153 other institutions or organizations, 16 of which had more than 10 publications. The authors of 576 publications were the researchers of SI «V.P. Komisarenko Institute of Endocrinology and Metabolism of the National Academy of Medical Sciences of Ukraine»; 38 scientists were authors of 10 or more publications. Conclusions. In recent years, the publication activity has remained stable.

Keywords: journal «Endokrynologia», scientific publication, bibliometric analysis.

Для цитування: Пастер ІП. Бібліометричний аналіз наукових публікацій у журналі «Ендокринологія». Ендокринологія. 2020;25(4):316-325. DOI: 10.31793/1680-1466.2020.25-4. 316.

Відомості про автора: Ігор Петрович Пастер, канд. мед. наук, старш. наук. співроб., e-mail: pasteur@ukr.net, ORCID: 0000-00028199-833X.

Особистий внесок: І.П. Пастер - повна підготовка статті.

Фінансування: стаття підготовлена за власні кошти автора.

Декларація з етики: автор задекларував відсутність конфлікту інтересів і фінансових зобов'язань. 